\title{
Effect of an Agri-environmental Measure on Nitrate Leaching from a Beef Farming System in Ireland
}

K.G. Richards ${ }^{1 *}$, M.M.R. Jahangir ${ }^{1,2}$, M. Drennan ${ }^{3}$, J.J. Lenehan ${ }^{3}$, J. Connolly ${ }^{4}$, C. Brophy $^{4}$, O.T. Carton ${ }^{1}$

${ }^{1}$ Teagasc, Johnstown Castle Environment Research Centre, Co. Wexford, Ireland;

${ }^{2}$ Department of Civil, Structural \& Environmental Engineering, Trinity College Dublin, Ireland; ${ }^{3}$ Teagasc, Grange, Dunsany, Co. Meath, Ireland; ${ }^{4}$ School of Mathematical Sciences, University College Dublin, Ireland

\section{*Corresponding author:}

Dr. Karl Richards

Teagasc, Johnstown Castle Environment Research Centre, Co. Wexford, Ireland

Email: karl.richards@ teagasc.ie

Tel: $+353-53-9171200$

Fax: 353-53-9142213 


\section{Abstract}

Agricultural Nitrogen $(\mathrm{N})$ management remains a key environmental challenge. Improving $\mathrm{N}$ management is a matter of urgency to reduce the serious ecological consequences of the reactive $\mathrm{N}$. Nitrate $\left(\mathrm{NO}_{3}{ }^{-} \mathrm{N}\right)$ leaching was measured under suckler beef production systems stocked at two intensities: 1 . Intensive, $210 \mathrm{~kg}_{\text {organic }} \mathrm{N} \mathrm{ha}^{-1}$ with two cut silage harvests; and 2. Rural Environmental Protection Scheme (REPS), $170 \mathrm{~kg}$ organic $\mathrm{N} \mathrm{ha}^{-1}$ with one cut silage harvest. Three replicate plots of each treatment were instrumented with ceramic cups ( 8 per plot), randomly placed within each plot at a depth of $1 \mathrm{~m}$ to collect soil solution for $\mathrm{NO}_{3}{ }^{-} \mathrm{N}$ at $50 \mathrm{kPa}$ suction to collecting vessels one week prior to sampling. Samples were taken on a total of 53 sampling dates over 3 winter drainage periods (2002/03, 2003/04 and 2004/05). Over the course of the experiment the mean annual soil solution $\mathrm{NO}_{3}{ }^{-} \mathrm{N}$ concentration exceeded the MAC twice out of 15 means (5 treatments over 3 years). The REPS grazing and silage sub treatments had significantly lower mean annual soil solution total oxidized $\mathrm{N}$ (TON) concentrations than the respective intensive treatments in years 2 and 3. Annual total $\mathrm{NO}_{3}{ }^{-} \mathrm{N}$ losses over the three years in Intensive and REPS systems ranged from 55 to 71 and 15 to $20 \mathrm{~kg} \mathrm{~N} \mathrm{ha}^{-1}$, respectively. Mean $\mathrm{N}$ surpluses in Intensive and REPS systems were 210 and $95 \mathrm{~kg} \mathrm{ha}^{-1}$, respectively with the corresponding mean $\mathrm{N}$ inputs of 272 and $124 \mathrm{~kg} \mathrm{~N} \mathrm{ha}^{-1}$. The reduction in $\mathrm{N}$ inputs under the REPS system results in lower $\mathrm{N}$ leaching losses and contributed to a significant reduction in pressures on water quality.

Keywords: Nitrate leaching, drainage, beef farming, REPS, agri-environment, water quality 


\section{Introduction}

Improving water quality in Ireland, in particular for the eutrophication in lakes, rivers and coasts, remains one of the key environmental challenges (Fenton et al., 2011; Toner et al., 2005). Among the substances responsible for eutrophication, nitrate $\left(\mathrm{NO}_{3}{ }^{-} \mathrm{N}\right)$ leaching from agricultural soils is by far the most important contributor (Nguyen et al., 2010). There has been considerable legislation, at the European and national levels, which has lead to the introduction of the Nitrates Directive (1991/676/EC) and the Water Framework Directive (2000/60/EC). Both of these legislative instruments require mandatory actions and measures to be introduced to ensure good water quality (Stark and Richards, 2008). The 2007-2009 biological surveys (McGarrigle et al., 2010) has shown another slight improvement in overall surface water quality, with $69 \%$ of river channel length classified as unpolluted. On the other hand national groundwater quality is still under threat as $40 \%$ of the monitoring locations showed $10-25 \mathrm{mg} \mathrm{NO}_{3}^{-} \mathrm{L}^{-1}, 16 \%$ of the monitoring locations exceeded $25 \mathrm{mg} \mathrm{L}^{-1} \mathrm{NO}_{3}{ }^{-}$and $3 \%$ exceeded $50 \mathrm{mg} \mathrm{L}^{-1} \mathrm{NO}_{3}{ }^{-}$ (Craig et al., 2010).

In Europe, Agri-Environmental Measures (AEMs) were established to reduce agricultural impacts on the environment and positively contribute to environmental protection and enhancement. They were introduced through a number of EU regulations such as 797/85 EC and 2078/92. The implementation of AEMs is compulsory at the national level and was optional for farmers within member states. The Rural Environmental Protection Scheme (REPS) was established in 1994 as Ireland's AEM. The scheme was designed to financially reward farmers for carrying out their farming practices in an environmentally friendly manner and to ensure good environmental practice on farms. REPS places compulsory limits on inorganic fertiliser $\mathrm{N}$ rates, 
application timing and the overall farm stocking rate must be below $170 \mathrm{~kg}$ organic $\mathrm{N}$ $\mathrm{ha}^{-1}$. It also contains a large range of other compulsory and optional measures with a particular focus on enhancement of biodiversity. A comprehensive study of the environmental impacts of REPS has been absent in Ireland (Finn and hUallacháin, 2011).

The REPS scheme in Ireland was attractive to farmers, an estimated $31 \%$ of Irish farms received REPS payments in 2004 (Connolly et al., 2005). Almost 74\% of farms which participate in REPS are in the three dry stock systems, namely Cattle Rearing, Cattle Other and Mainly Sheep (Connolly et al., 2005). Reduced fertiliser N inputs to grazed permanent grassland should lead to decreased $\mathrm{NO}_{3}{ }^{-}$leaching rates. Over an 8 year period, $\mathrm{NO}_{3}^{-}-\mathrm{N}$ leaching was 38 and $129 \mathrm{~kg} \mathrm{~N} \mathrm{ha}^{-1}$ on a clay loam soil (Scholefield et al., 1993) receiving fertilizer inputs of 200 and $400 \mathrm{~kg} \mathrm{~N} \mathrm{ha}^{-1}$. Watson et al. (2000) reported a significant positive relationship between fertilizer $\mathrm{N}$ application rate (100$500 \mathrm{~kg} \mathrm{~N} \mathrm{ha}^{-1}$ ) and load of $\mathrm{NO}_{3}{ }^{-}-\mathrm{N}$ leached. Published schemes on $\mathrm{NO}_{3}{ }^{-}-\mathrm{N}$ leaching in Irish agricultural system is scarce and the studies highlighted the potential threat of $\mathrm{NO}_{3}{ }^{-} \mathrm{N}$ to surface and groundwater pollution. There has been no evaluation of the efficacy of REPS in reducing nutrient loss to water. Ryan et al (2006) estimated mean $\mathrm{NO}_{3}{ }^{-}$and $\mathrm{NH}_{4}{ }^{+}$concentrations of 8.2 and $0.30 \mathrm{mg} \mathrm{N} \mathrm{L}{ }^{-1}$ leachate, respectively at $1 \mathrm{~m}$ bgl (free draining soil) under dairy systems where mean $\mathrm{N}$ input and stocking density were $319 \mathrm{~kg} \mathrm{ha}^{-1}$ and $2.38 \mathrm{LU} \mathrm{ha}^{-1}$. Similar to grass, cereal-growing on recently ploughed grassland on well drained soils receiving 75-100 $\mathrm{kg} \mathrm{N} \mathrm{ha}^{-1}$, poses a significant risk to water quality from leaching of $\mathrm{NO}_{3}{ }^{-}$(Ryan et al., 2001). Farmers and regulators urge the need to improve $\mathrm{N}$ recovery in agricultural systems. For example EU directives impose pressure on agriculture to make more efficient use of $\mathrm{N}$. The objective of this 
study was to examine the effect of reduced animal stocking rate and associated fertiliser $\mathrm{N}$ inputs on $\mathrm{NO}_{3}{ }^{-}$leaching under suckler beef production on a moderately well drained clay loam soil in Ireland.

\section{Materials and Methods}

\subsection{Study site description}

The study was carried out at Teagasc, Grange research centre which is located in Dunsany, Co. Meath, Ireland $\left(53^{\circ} 32^{`} \mathrm{~N}, 6^{\circ} 31^{`} \mathrm{E}\right)$ at $60 \mathrm{~m}$ above sea level. The research farm focuses on beef and suckler production and is mainly comprised of permanent grassland. The soils on the farm were mapped in detail by Gardiner (1962). The area is underlain by gravely, limestone boulder clay with occasional sorted sands and gravels. The soils are derived from the boulder drift cover and vary between clay loam and clays. The plots investigated comprised of moderately well drained, brown earth, clay loam soils of high base status. The FAO classification of the soil underlying the site is an Orthic Luvisols (Kurz et al., 2006).

\subsection{Farming systems}

Nitrate leaching was quantified under two suckler beef production systems in the final 3 years of an 8 year agronomic systems experiment. The agronomic systems experiment was conducted from 1997 to 2005. Drennan and McGee (2009) described the agronomic design of the experiment in detail. Spring-calving beef suckler cows were introduced in 2001 and 2002 which consisted of Limousin $\times$ (Limousin $\times$ HolsteinFriesian), purebred Limousin and purebred Charolais. The suckler beef systems were 


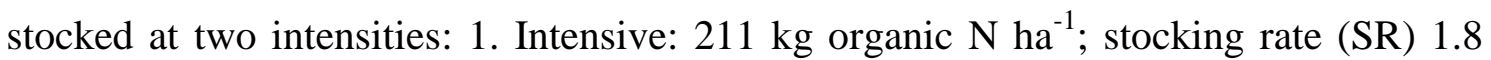
and 1.4 for bull and steer production, respectively and 2. REPS: $170 \mathrm{~kg}$ organic $\mathrm{N} \mathrm{ha}^{-1}$; SR 1.4 and 1.1 for bull and steer production, respectively. Number of silage harvests was 2 and 1 for Intensive and REPS, respectively. Both treatments were managed as systems and grazing/silage plots were allocated in a randomised block design. A summary of the treatments, system intensity, grassland management and nutrient source applied to treatments was outlined in Table 1.

Animals were grazed on permanent grassland plots from April to October/November depending on weather and soil conditions. The grazing events during the whole grazing period in every year took place for 7, 5 and 4 times at every 4 week interval for grazing only, one cut silage and 2 cut silage, respectively. During the winter period animals were housed in slatted floor sheds and offered grass silage conserved from within their respective systems. Silage was harvested in both systems for feeding during the winter housing period. In the intensive system there were two silage harvests, May and August each year. Silage was harvested in once in the REPS system in late May/early June. The total annual fertiliser and manure $\mathrm{N}$ application rates for each system during the 3 years of the study are outlined in Table 1 . Manure was applied $\left(33 \mathrm{~m}^{3} \mathrm{ha}^{-1}\right)$ to the silage plots in spring and summer before or after first cut and after second cut silage and the manure $\mathrm{N}$ application rates are shown in Table 1. All plots received recommended rates of $\mathrm{P}$ and $\mathrm{K}$ fertiliser each year based on annual soil test results.

\subsection{Soil solution sampling}

Three replicate plots of each treatment were instrumented with ceramic cups (Soil Moisture Inc., California, USA); there were 8 cups per plot inserted at a depth of $1 \mathrm{~m}$ 
having a bentonite seal, $150 \mathrm{~mm}$ below ground surface, around the connecting tube. Ceramic cups were randomly placed within each plot as described by Ryan et al. (2006). Soil solution was sampled by applying $50 \mathrm{kPa}$ suction to collecting vessels one week prior to sampling. Samples were taken on a total of 53 sampling dates over 3 winter drainage periods 2002/03 (year 1), 2003/04 (year 2) and 2004/05 (year 3). The samples were stored and transported at $4{ }^{\circ} \mathrm{C}$ to the analytical laboratories in Teagasc, Johnstown Castle. Soil solution samples were analysed within 48 hours of sampling for $\mathrm{NO}_{3}{ }^{-} \mathrm{N}$ colorimetrically by hydrazine reduction (USEPA, 1983a) with a Konelab 30 discrete autoanalyzer (Konelab Corporation, Espoo, Finland). Quality checks were also carried out where tolerances for high and low values were within $90 \%$ and $10 \%$ of top standard.

\subsection{Water balance}

Meteorological data collected at the experimental site was used to calculate effective rainfall or drainage which is an estimate of the quantity of water that percolates through soil to groundwater. Potential evapotranspiration was calculated using the FAO Penman-Montieth equation (Allen et al., 1998) and this was converted to actual evapotranspiration using an Aslyng scale recalibrated for Irish conditions (Schulte et al., 2005). Effective rainfall was calculated by subtracting daily actual evapotranspiration from daily rainfall.

\subsection{Nitrate leaching loads}

Load of $\mathrm{NO}_{3}{ }^{-} \mathrm{N}$ leached was calculated using the trapezoidal rule (Lord and Shepherd, 1993). The area under the plot of $\mathrm{NO}_{3}{ }^{-} \mathrm{N}$ concentration against drainage was calculated as the sum areas of the trapezia resulting from successive pairs of sampling occasions 
$\left(c_{1}, c_{2} \mathrm{mg} \mathrm{L}^{-1}\right)$ and the drainage volume between sampling occasions $(d v \mathrm{~mm})$. The total $\mathrm{N}$ leached $\left(\mathrm{kg} \mathrm{ha}^{-1}\right)$ in each sampling interval was: $\mathrm{kg} \mathrm{N}$ leached $=0.5\left(c_{1}+c_{2}\right) d v / 100$.

\subsection{System $\mathrm{N}$ balance}

A nitrogen balance was calculated for each of the suckler systems. Farm gate $\mathrm{N}$ inputs quantified include inorganic fertiliser and concentrated feed; atmospheric deposition was estimated using data from Ryan et al. (2006). Nitrogen outputs measured include animal uptake (live weight gain) and leaching; estimated losses include $\mathrm{NH}_{3}$ and $\mathrm{N}_{2} \mathrm{O}$. The $\mathrm{N}$ surplus was calculated by subtracting total outputs from total inputs.

\subsection{Statistical analysis}

2.7.1 Analysis of annual average $\mathrm{NO}_{3}{ }^{-} \mathrm{N}$ concentrations in plot drainage water:

The annual average $\mathrm{NO}_{3}{ }^{-} \mathrm{N}$ concentration was analysed using a repeated measures analysis over each of the three years. The data consisted of 45 values for each $\mathrm{N}$ type (5 treatments x 3 replicates x 3 years). These aggregated data were not normally distributed. A generalized linear mixed model was fitted that assumed a Gamma (positively skewed) distribution and incorporated a log link and allowed for the repeated measures nature of the data (Littell et al., 1996; Ryan et al., 2006). An appropriate correlation structure was used to describe the relationship among the repeated values across years. 


\subsubsection{Analysis of weekly average $N$ concentrations in plot drainage water:}

Within each year a repeated measures analysis on the average concentration (over 8 cups) per plot per week, using the modelling strategy described for the annual concentration data, was performed.

\subsubsection{Analysis of annual $\mathrm{NO}_{3}{ }^{-}-\mathrm{N}$ loads leached}

The annual calculated $\mathrm{NO}_{3}{ }^{-} \mathrm{N}$ load leached was analysed using a repeated measures analysis over each of the three years. The data consisted of 45 values for each $\mathrm{N}$ type (5 treatments $\times 3$ replicates $\times 3$ years) and the data were analysed as outlined for the analysis of annual average $\mathrm{N}$ concentrations in plot drainage water above.

Statistical analysis was carried out using the GLIMMIX procedure in the SAS/STAT software Version 9.1 of the SAS System for Windows (SAS Institute Inc., Cary, NC, USA). Means predicted from models with a log link are back-transformed to give means for presentation on the scale of measurement. A Least Significant Ratio (LSR) is used to compare significant differences between the mean treatment soil solution $\mathrm{NO}_{3}^{-}$$\mathrm{N}$ concentration and $\mathrm{NO}_{3}{ }^{-} \mathrm{N}$ load leached. If the ratio of the larger mean to the smaller mean is greater than the LSR, then the two means differ at the 0.05 (or as specified) confidence level. 


\section{Results}

\subsubsection{Rainfall and effective rainfall}

Cumulative rainfall in 2002, 2003 and 2004 was 1066, 743 and $864 \mathrm{~mm}$ per year, respectively. The average annual air temperature was very similar during the year 2002, 2003 and 2004; and was 10.6, 9.9 and $10.2{ }^{\circ} \mathrm{C}$, respectively. The long term (1971-2001) average annual rainfall and temperature at the site are $849 \mathrm{~mm}$ and $9.1{ }^{\circ} \mathrm{C}$. In contrast to the cumulative annual rainfall, the cumulative rainfall patterns during the 3 winter drainage periods were broadly similar, with 439, 490 and $430 \mathrm{~mm}$ in years 1, 2 and 3, respectively. There were larger differences apparent in the calculated drainage volumes over the 3 winter period with 303, 226 and $251 \mathrm{~mm}$ drainage during year 1, 2 and 3, respectively (Fig. 1). The majority of drainage was calculated to have occurred during the ceramic cup sampling period with only small amounts occurring outside these sampling periods.

\subsubsection{Annual soil solution $\mathrm{NO}_{3}{ }^{-}-\mathrm{N}$ concentrations}

The mean annual $\mathrm{NO}_{3}{ }^{-}-\mathrm{N}$ concentrations observed within all the treatments ranged 2.1 to $8.4,1.7$ to 20.3 and 0.7 to $15.5 \mathrm{mg} \mathrm{N}^{-1}$ in years 1,2 and 3 , respectively. The mean annual soil solution $\mathrm{NO}_{3}{ }^{-}-\mathrm{N}$ concentration exceeded the EU MAC twice out of a total of 15 means ( 5 treatments by 3 years $)$. There was a significant $(\mathrm{p}<0.01)$ year by treatment interaction observed in the $\mathrm{NO}_{3}{ }^{-} \mathrm{N}$ data. Significant differences between the mean annual soil solutions $\mathrm{NO}_{3}{ }^{-}-\mathrm{N}$ concentrations are summarised for all treatments in Table 2. No significant differences were observed within the mean annual $\mathrm{NO}_{3}{ }^{-}-\mathrm{N}$ between any treatments in year 1 . Within the grazing only treatments $\mathrm{T} 4$ had a significantly $(\mathrm{p}<0.01)$ lower mean annual soil solution $\mathrm{NO}_{3}{ }^{-}-\mathrm{N}$ concentration than $\mathrm{T} 1$ in years 2 and 
3. Mean annual $\mathrm{NO}_{3}{ }^{-} \mathrm{N}$ concentrations within the silage areas were significantly lower in T5 than in both T2 and T3 for years 2 and year 3. The LSRs were slightly lower in years 2 and 3 (3.5 and 3.7, respectively) compared to 4.0 in year 1.

\subsubsection{Mean weekly soil solution $\mathrm{NO}_{3}-\mathrm{N}$ concentrations}

The temporal variation of weekly soil solution $\mathrm{NO}_{3}{ }^{-}-\mathrm{N}$ concentrations is presented in Figure $3 \mathrm{a}$ to $3 \mathrm{c}$. Within the grazed only treatments, T4 had consistently lower mean weekly $\mathrm{NO}_{3}{ }^{-} \mathrm{N}$ than $\mathrm{T} 1$. Over the three years of the study the mean weekly $\mathrm{NO}_{3}{ }^{-} \mathrm{N}$ concentrations in $\mathrm{T} 4$ were mostly $<5 \mathrm{mg} \mathrm{L}^{-1}$, on 4 sampling dates in year 2 the concentrations were $>5 \mathrm{mg} \mathrm{L}^{-1}$. Whereas in $\mathrm{T} 1$ the mean weekly $\mathrm{NO}_{3}^{-}-\mathrm{N}$ concentrations over the 3 years was generally between 5 and $10 \mathrm{mg} \mathrm{l}^{-1}$, the mean on 5 dates was $<5 \mathrm{mg}$ $\mathrm{L}^{-1}$ and on 4 dates $>10 \mathrm{mg} \mathrm{L}^{-1}$.

Nitrate leaching was generally lower in the silage area in comparison to the grazed only. In $\mathrm{T} 2$ the range of mean weekly $\mathrm{NO}_{3}{ }^{-} \mathrm{N}$ concentrations varied over the three years of the study; the ranges were $<5 \mathrm{mg} \mathrm{N} \mathrm{L}^{-1}$ year $1,5-10 \mathrm{mg} \mathrm{N} \mathrm{L}^{-1}$ in year 2 and $>10 \mathrm{mg} \mathrm{N}$

$\mathrm{L}^{-1}$ in year 3. The same pattern was also evident in $\mathrm{T} 3$ where the mean weekly $\mathrm{NO}_{3}{ }^{-} \mathrm{N}$ concentrations ranged $<5 \mathrm{mg} \mathrm{N} \mathrm{L}^{-1}$ in year $1,>10 \mathrm{mg} \mathrm{N} \mathrm{L}^{-1}$ in year 2 and $5-10 \mathrm{mg} \mathrm{N} \mathrm{L}^{-1}$ in year 3. Significant interactions were observed between sampling date and treatment in year $1(\mathrm{p}<0.0001)$, year $2(\mathrm{p}<0.05)$ and year $3(\mathrm{p}<0.01)$. The number of sampling dates, within a year, on which the mean soil solution $\mathrm{NO}_{3}{ }^{-}-\mathrm{N}$ concentrations were significantly different between selected treatments are summarised in Table 3 .

Within the grazed only plots, the mean weekly $\mathrm{NO}_{3}{ }^{-}-\mathrm{N}$ concentration was significantly lower in $\mathrm{T} 4$ compared to $\mathrm{T} 1$ on $55 \%$ of the sampling dates in year $1,10 \%$ of the 
sampling dates in year 2 and $60 \%$ of the sampling dates in year 3. Overall T4 had significantly lower mean $\mathrm{NO}_{3}{ }^{-} \mathrm{N}$ concentrations than $\mathrm{T} 1$ on $43 \%$ of all sampling dates (23 of 53 dates). For the silage and aftermath grazing treatments, T5 had significantly lower weekly $\mathrm{NO}_{3}{ }^{-} \mathrm{N}$ concentrations than $\mathrm{T} 2$ on 11,38 and $95 \%$ of the sampling dates in years 1,2 and 3, respectively. In total the mean weekly $\mathrm{NO}_{3}{ }^{-} \mathrm{N}$ concentrations in $\mathrm{T} 5$ were significantly lower than $\mathrm{T} 2$ on $51 \%$ of all sampling dates. Weekly mean $\mathrm{NO}_{3}{ }^{-} \mathrm{N}$ concentrations were significantly lower in T5 than T3 on 16, 100 and $100 \%$ of the sampling dates in years 1,2 , and 3 , respectively. Over all mean weekly $\mathrm{NO}_{3}{ }^{-} \mathrm{N}$ concentrations were significantly lower in $\mathrm{T} 5$ than $\mathrm{T} 3$ on $70 \%$ of all sampling dates.

\subsubsection{Annual loads of $\mathrm{NO}_{3}{ }^{-}-\mathrm{N}$ leached}

The calculated mean annual $\mathrm{NO}_{3}^{-}-\mathrm{N}$ load leached $\left(\mathrm{kg} \mathrm{N} \mathrm{ha}^{-1} \mathrm{yr}^{-1}\right)$ by treatment and year, the annual least significant ratio and the statistical summary comparing treatment means are presented in Table 4. In year 1 , the mean annual $\mathrm{NO}_{3}{ }^{-} \mathrm{N}$ loads leached ranged from 6.6 to $24.2 \mathrm{~kg} \mathrm{~N} \mathrm{ha}^{-1} \mathrm{y}^{-1}$ with being 7-24 $\mathrm{kg} \mathrm{N}^{-1} \mathrm{y}^{-1}$ in Intensive and 7-10 $\mathrm{kg} \mathrm{N}^{-1} \mathrm{y}^{-1}$ in REPS. In year 2, the mean annual $\mathrm{NO}_{3}{ }^{-}-\mathrm{N}$ loads leached ranged 3.5 to $44.9 \mathrm{~kg} \mathrm{~N}^{-1}$ $\mathrm{y}^{-1}$; leaching under REPS treatments were $<10 \mathrm{~kg} \mathrm{~N} \mathrm{ha}^{-1} \mathrm{y}^{-1}$ and Intensive treatments were $>10 \mathrm{~kg} \mathrm{~N} \mathrm{ha}^{-1} \mathrm{y}^{-1}$. In year 3, mean annual $\mathrm{NO}_{3}{ }^{-} \mathrm{N}$ loads leached ranged from 1.9 to 41.4 $\mathrm{kg} \mathrm{N} \mathrm{ha}^{-1} \mathrm{y}^{-1}$; the REPS treatments had leaching losses $<5 \mathrm{~kg} \mathrm{~N} \mathrm{ha}^{-1} \mathrm{y}^{-1}$ whereas Intensive treatments had $>15 \mathrm{~kg} \mathrm{~N} \mathrm{ha}^{-1} \mathrm{y}^{-1}$. Over the 3 years of the experiment, the total load of $\mathrm{NO}_{3}^{-}-\mathrm{N}$ leached ranged from 15 to $70.7 \mathrm{~kg} \mathrm{~N} \mathrm{ha}^{-1} \mathrm{y}^{-1}$. The 3 year total losses from the two REPS treatments were each $<20 \mathrm{~kg} \mathrm{~N} \mathrm{ha}^{-1} \mathrm{y}^{-1}$ and the Intensive treatments were each $>50 \mathrm{~kg} \mathrm{~N} \mathrm{ha}^{-1} \mathrm{y}^{-1}$. Total $\mathrm{NO}_{3}{ }^{-} \mathrm{N}$ leached over the three winter drainage periods were significantly lower in REPS compared to Intensive $(\mathrm{p}=0.012)$. The average for different managements over the three years loads of $\mathrm{NO}_{3}{ }^{-} \mathrm{-N}$ leached were 63.1 and 17.3 $\mathrm{kg} \mathrm{ha}^{-1}(\mathrm{SED}=14.9)$ for intensive and REPS, respectively. 
There was a significant year by treatment interaction $(\mathrm{p}<0.05)$. In year 1 , no significant differences were observed between the treatments mean $\mathrm{NO}_{3}{ }^{-}-\mathrm{N}$ loads leached (Table 4). Within the silage + grazing treatments, mean $\mathrm{NO}_{3}{ }^{-}-\mathrm{N}$ loads leached under $\mathrm{T} 5$ were significantly lower than T2 in year $2(\mathrm{p}<0.05)$, year $3(\mathrm{p}<0.01)$ and T5 was significantly lower than T3 $(\mathrm{p}<0.01)$ in both years 2 and 3 (Table 4). In the grazed only treatments, in year 3, T4 had significantly lower mean $\mathrm{NO}_{3}{ }^{-}-\mathrm{N}$ loads leached than $\mathrm{T} 1$.

\subsubsection{System $\mathrm{N}$ balance}

Total $\mathrm{N}$ inputs and outputs were much higher in the intensive system than the REPS. Over the 3 year period inputs ranged from 253 to $288 \mathrm{~kg} \mathrm{~N} \mathrm{ha}^{-1}$ and 124 to $125 \mathrm{~kg} \mathrm{~N}^{-}$

1 , respectively in intensive and REPS systems (Table 5). Lower $\mathrm{N}$ inputs in REPS system resulted in a lower losses of $\mathrm{N}$ by volatilisation, denitrification and leaching (Table 5). The annual N surpluses were approximately 50\% lower in the REPS than the Intensive systems. The REPS system appeared to have shown a significantly lower $\mathrm{N}$ surplus in the environment. Even though the mean output in the Intensive system was higher than the REPS system, the $\mathrm{N}$ output via live weight gain were higher in Intensive systems only by $2-3 \mathrm{~kg} \mathrm{ha}^{-1}$.

\section{Discussion}

4.1 Annual $\mathrm{NO}_{3}{ }^{-}-\mathrm{N}$ leaching in REPS and Intensive systems

The observed $\mathrm{NO}_{3}{ }^{-}-\mathrm{N}$ leaching losses from all the treatments in this study are generally lower than the EU MAC. Over the course of the experiment the mean annual soil 
solution $\mathrm{NO}_{3}{ }^{-}-\mathrm{N}$ concentration exceeded the MAC twice out of 15 means ( 5 treatments over 3 years). The moderately well drained clay loam soil would not be as susceptible to $\mathrm{NO}_{3}{ }^{-}-\mathrm{N}$ leaching and even under high annual fertiliser inputs of up to $245 \mathrm{~kg} \mathrm{~N} \mathrm{ha}^{-1}$. Similar soil solution $\mathrm{NO}_{3}{ }^{-} \mathrm{N}$ concentrations between treatments in year 1 could be attributed to the higher drainage in this year than other two years; and the residual $\mathrm{NO}_{3}{ }^{-}-$ $\mathrm{N}$ effects from the previous years. However, the significant differences in soil solution $\mathrm{NO}_{3}{ }^{-} \mathrm{N}$ between treatments in the latter two years of the study (Year 2 and 3) rather indicate the consistency in higher $\mathrm{NO}_{3}{ }^{-} \mathrm{N}$ leaching under Intensive system than the REPS. There was an association between $\mathrm{N}$ fertiliser input and mean annual $\mathrm{NO}_{3}{ }^{-} \mathrm{N}$ concentration but this was not significant $(\mathrm{p}=0.007)$. The relationship between fertiliser input and $\mathrm{NO}_{3}{ }^{-} \mathrm{N}$ leaching is probably confounded by a variation in stocking rate between the treatments. The stocking rate in Intensive system was 0.25 higher than the Extensive system (Drennan and McGee, 2009). Higher stocking rate would require higher $\mathrm{N}$ inputs which will eventually increase $\mathrm{N}$ leaching to groundwater. However, impact of grazing and $\mathrm{N}$ management practices on $\mathrm{N}$ leaching in grazing system is complicated by many factors: site weather conditions, sources of $\mathrm{N}$ (organic vs inorganic), $\mathrm{N}$ application time and grazing intensity (Huebsch et al., 2013). In this study in 2002/03 $\mathrm{NO}_{3}{ }^{-} \mathrm{N}$ leaching in $\mathrm{T} 2$ and $\mathrm{T} 3$ was acceptable but not in the later years (Table 4). This could be attributed to high rainfall in the immediately previous year which have flushed out soil pore water $\mathrm{NO}_{3}{ }^{-} \mathrm{N}$ to groundwater and reduced $\mathrm{NO}_{3}{ }^{-} \mathrm{N}$ leaching in the following year. High rainfall events coincide with major mobilisation of $\mathrm{NO}_{3}{ }^{-} \mathrm{N}$ (Drew and Hotzl, 1999). Bartley (2003) showed that groundwater $\mathrm{NO}_{3}{ }^{-} \mathrm{N}$ concentrations were highest in the areas of highest organic $\mathrm{N}$ loadings. Switching application time can significantly increase $\mathrm{N}$ use efficiency and thus can reduce $\mathrm{NO}_{3}{ }^{-}-\mathrm{N}$ leaching (Huebsch et al., 2013). Increased grazing intensity can 
increase $\mathrm{NO}_{3}{ }^{-}-\mathrm{N}$ leaching in the vulnerable soil conditions (Huebsch et al., 2013). With regards to all these aspects of $\mathrm{N}$ management and animal number, the REPS system has higher potential than the Intensive system to reduce $\mathrm{NO}_{3}{ }^{-} \mathrm{N}$ leaching.

Participation in the REPS scheme by farmers increased steadily to $45 \%$ of the total farms in 2006 after its initiation in 1994. The REPS systems appeared to have shown a significant reduction in total $\mathrm{NO}_{3}{ }^{-} \mathrm{N}$ leaching over the three years. Total annual losses of $\mathrm{NO}_{3}{ }^{-} \mathrm{N}$ over the three years in various managements ranged from $55-71 \mathrm{~kg} \mathrm{~N} \mathrm{ha}^{-1}$ under Intensive system and from $15-20 \mathrm{~kg} \mathrm{~N} \mathrm{ha}^{-1}$ under REPS system. This reduction in $\mathrm{NO}_{3}{ }^{-} \mathrm{N}$ leaching implies that the REPS system can be an environment friendly beef production system in Ireland. Lawes et al. (2000) reported that reducing fertiliser N use reduces the $\mathrm{N}$ surplus in beef systems. However in beef systems, the reduced stocking density and fertiliser $\mathrm{N}$ in an extensive system do not affect the performance of individual animals. So in accord with previous findings, Peyraud and Astigarraga (1998) suggested that lowering the levels of $\mathrm{N}$ fertiliser with a concurrent reduction in stocking density reduces $\mathrm{N}$ losses of ruminants with little or no change in their nutrition or in individual performance. Drennan and McGee (2009) found a similar performance of individual bull in two systems: 1) Intensive (stocking density 0.56 with fertiliser $\mathrm{N}$ $211 \mathrm{~kg} \mathrm{ha}^{-1}$ ) and 2) Extensive (stocking density 0.69 with fertiliser $\mathrm{N} 97 \mathrm{~kg} \mathrm{ha}^{-1}$ ), indicating that substitution of fertiliser $\mathrm{N}$ with additional land would not affect the beef production. Their Extensive system was compatible with the REPS systems in this study with regards to $\mathrm{N}$ losses to the environment. After a review of available publications on the impact of REPS on water quality, Finn and hUallacháin (2011) concluded that REPS system appears to have shown very significant improvements in the management and storage of nutrients and agro-chemicals, which would contribute to a significant 
reduction in pressures on water quality. The leached $\mathrm{N}$ concentrations were generally below the MAC and overall leaching was substantially lower than the IPCC $(30 \%$ default value).

The limits placed on farmers by the REPS scheme could be seen as reducing the farmers potential for innovation as they have to operate within stringent fertiliser and stocking rates. The scheme was attractive to less intensive farmers who could operate within these limits due to the reduced productivity on their farms. This input control based agri-environmental policy pays farmers for the completion of actions rather than the benefits that arise from actions. Input control policies are often viewed with resentment and put farmers off participation in such schemes (Vickery et al. 2004). The rewarding of farmers for performing actions can reduce rather than promote motivation and innovation (Deci et al. 1999). At the EU level there has been a moved towards results oriented agri-environmental schemes which encourage results or outcomes rather than actions or behaviours. These result oriented schemes would reward farmers for the provisions of environmental goods and services but they have two limitations. Firstly the difficulty of developing the monitoring indicators to evaluate schemes against and secondly there is an increased risk of the scheme to the farmer (Burton and Schwarz 2013). The financial incentives linked to results oriented schemes directly links to the desired environmental objectives but encourage innovation for the farmer to choose the most efficient way to achieve the objectives. The move to results oriented agrienvironmental schemes has been shown to be cost effective (Matzdorf and Lorenz, 2010). For example catchment level reduction of $\mathrm{N}$ surpluses could be achieved through cooperative incentivisation as part of the results oriented scheme. 


\subsection{System $\mathrm{N}$ balance}

In Irish grassland system, studies have shown that annual $\mathrm{N}$ surpluses increased with increasing $\mathrm{N}$ inputs but recovery in products were declined (Humphreys et al., 2008). This Intensive grass-based farming contributes to large inputs of fertilizer $\mathrm{N}$ and thus indicates the potential risk of $\mathrm{NO}_{3}{ }^{-} \mathrm{N}$ delivery to groundwater and surface. More efficient $\mathrm{N}$ use is involved lower $\mathrm{N}$ inputs and in particular lower $\mathrm{N}$ concentrations in grazed herbage (Humphreys et al., 2008). In terms of the $\mathrm{N}$ surplus (input - output), REPS system had significant reduction in the environmental $\mathrm{NO}_{3}{ }^{-}-\mathrm{N}$ loads. Drennan and McGee (2009) reported N surplus of 216 and $95 \mathrm{~kg} \mathrm{~N}$ ha $^{-1}$ with an Intensive (216 $\left.\mathrm{kg} \mathrm{N} \mathrm{ha}^{-1}\right)$ and Extensive $\left(97 \mathrm{~kg} \mathrm{~N} \mathrm{ha}^{-1}\right)$ systems, respectively which was in agreement with the present study. The relatively lower $\mathrm{N}$ inputs in REPS system resulted in a lower $\mathrm{N}$ outputs than the intensive systems, because $\mathrm{N}$ losses by physico-chemical and biological processes were lower in REPS (Table 5). Therefore, REPS system had shown the high potential to a reduced $\mathrm{N}$ delivery to the environment. The estimated $\mathrm{N}$ input data in the Intensive system were comparable with the previous findings of beef farming in Ireland. Treacy et al. (2008) estimated the mean fertilizer N application rate of $223 \mathrm{~kg}$ $\mathrm{ha}^{-1}$. The $\mathrm{N}$ surplus data in the Intensive system was also in agreement with the other studies carried out in Irish grassland system. In Europe, grass based animals excrete $80 \%$, on average, of the $\mathrm{N}$ that they consume (Oenema, 2011). Jahangir et al. (2012) estimated an $\mathrm{N}$ surplus range of $137-263 \mathrm{~kg} \mathrm{~N} \mathrm{ha}^{-1}$ in Irish grazed grassland systems. From a survey in 21 dairy farms during 2003-2006, Treacy et al. (2008) estimated the mean $\mathrm{N}$ surplus of $232 \mathrm{~kg} \mathrm{~N} \mathrm{ha}^{-1}$. The lower rate of $\mathrm{N}$ surplus in REPS demonstrates the potential of the system to be a sustainable beef production practices with a corresponding low $\mathrm{N}$ polluted environment. The low $\mathrm{N}$ release in the environment in turns will help reduce eutrophication in lakes, rivers and coastal waters. 


\section{Conclusion}

The REPS system significantly reduced $\mathrm{N}$ use and the total $\mathrm{NO}_{3}{ }^{-}-\mathrm{N}$ leaching over the study period. The REPS grazing and silage sub treatments had significantly lower mean annual soil solution $\mathrm{NO}_{3}{ }^{-} \mathrm{-N}$ concentrations than the respective intensive treatments in years 2 and 3. The reduced stocking rate and fertiliser inputs in REPS significantly reduced $\mathrm{NO}_{3}{ }^{-}-\mathrm{N}$ leaching on this site. Mean $\mathrm{N}$ inputs and surpluses were significantly lower in REPS than the Intensive system. This reduction in $\mathrm{NO}_{3}{ }^{-}-\mathrm{N}$ leaching implies that the REPS system can be an environmentally friendly beef production system. Therefore, the REPS system can be considered as an improved $\mathrm{N}$ management system that will help achieve and maintain the 'Good Ecological Status of Irish Water Bodies' and thus the target of EU Water Framework Directive and Nitrate Directive.

\section{Acknowledgements}

We acknowledgement all the hard work carried out by the technical and other staffs in water quality research group at Teagasc Environment Research Center. We also acknowledge the Irish Agricultural Advisory Authority (Teagasc) for the funding.

\section{References}

Allen, R.A., Pereira, L.S., Raes, D., Smith, M., 1998. Crop evapotranspiration. Guidelines for computing crop water requirements. FAO irrigation and drainage paper 56, FAO, Rome.

Bartley, P., 2003. Nitrate Responses in Groundwater Under Grassland Dairy Agriculture. University of Dublin, pp. 705.

Burton R. J. F., Schwarz G., 2013. Result-oriented agri-environmental promoting behavioural change. Land Use Policy 30, 628-641. 
Connolly, J., Kinsella, A., Quinlan, G., Moran, B., 2005 National Farm Survey 2004, Teagasc, Mellows Centre, Athenry, Co. Galway.

Craig, M., Mannix, A., Daly, D., 2010. Groundwater Quality. In: McGarrigle, M., Lucey, L., Ó Cinnéide, M. (Eds.), Water Quality in Ireland 2007-2009. Environmental Protection Agency, Ireland, p. 42.

Deci, E., Ryan, R., Koestner, R., 1999. A meta-analytic review of experiments examining the effects of extrinsic reward on intrinsic motivation. Psychological Bulletin 125, 627-668.

Drennan, M.J., McGee, M., 2009. Performance of spring-calving beef suckler cows and their progeny to slaughter on intensive and extensive grassland management systems. Livestock Sci. 120, 1-12.

Drew, D., Hötzl, H., 1999. Karst hydrogeology and human activities. Impacts, consequences and implications. Int. Contrib. Hydrogeol. 20, pp. 322.

Fenton, O., Schulte, R.P.O., Jordan, P., Lalor, S.T.J., Richards, K.G., 2011. Time lag: a methodology for the estimation of vertical and horizontal travel and flushing timescales to nitrate threshold concentrations in Irish aquifers. Environ. Sci. Policy 14, 419-431

Finn, J.A., hUallacháin, D.Ó., 2011. A review of evidence on the environmental impact of Ireland's Rural Environment Protection Scheme (REPS). Biology and Environment: Proceedings of the Royal Irish Academy 112B, doi: 10.3318/BIOE.2011.19.

Gardiner, M.J., 1962. The soils of the animal production research centre Grange. In: C. Meath, An Foras Taluntais, Soil Survey Bulletin No. 2, p. 11.

Huebsch, M., Horan, B., Blum, P., Richards, K.G., Grant, J., Fenton, O., 2013. Impact of agronomic practices of an intensive dairy farm on nitrogen concentrations in a karst aquifer in Ireland. Agril. Ecosyst. Environ. 179, 187-199. 
Humphreys, J., O’Connell, K., Casey, I.A., 2008. Nitrogen flows and balances in four grassland-based systems of dairy production on a clay-loam soil in a moist temperate climate. Grass Forage Sci. 63, 476-480.

Jahangir, M.M.R., Johnston, P., Khalil, M.I., Richards, K.G., 2012. Groundwater: A pathway for terrestrial $\mathrm{C}$ and $\mathrm{N}$ losses and indirect greenhouse gas emissions. Agric. Ecosysts. Environ. 159, 40-48.

Kurz, I., O'Reilly, C.D., Tunney, H., 2006. Impact of cattle on soil physical properties and nutrient concentrations in overland flow from pasture in Ireland, Agric. Ecosysts. Environ. 113, 378-390.

Lawes, J.A., Pain, B.F., Jarvis, S.C., Scholefield, D., 2000. Comparison of grassland management systems for beef cattle using self-contained farmlets: effects of contrasting nitrogen inputs and management strategies on nitrogen budgets, and herbage and animal production. Agric. Ecosysts. Environ. 80, 243-254.

Littell, R.C., Milliken, G.A., Stroup, W.W., Wolfinger, R.D., 1996. SAS System for Mixed Models. SAS institute Inc., Cary, NC, USA.

Lord, E.I., Shepherd, M.A., 1993. Developments in the use of porous ceramic cups for measuring nitrate leaching. J. Soil Sci. 44, 435-449.

Matzdorf, B., Lorenz, J., 2010. How cost-effective are result-oriented agrienvironmental measures?-An empirical analysis in Germany. Land Use Policy $27,535-544$.

McGarrigle, M., Bradley, C., Concannon, C., Cunningham, D., Kennedy, B., Lucey, J., McCreesh, P., MacCárthaigh, M., 2010. Water quality of rivers and canals. In: McGarrigle, M., Lucey, L., Ó Cinnéide, M. (Eds.), Water Quality in Ireland 2007-2009. Environmental Protection Agency, Ireland, p. 42.

Nguyen, T.H.T., Hermansen, J.E., Mogensen, L., 2010. Environmental consequences of different beef production systems in the EU. J. Cleaner Prod. 18, 756-766. 
Oenema, O., 2011. Mitigation of Nitrogen Emissions from Animal Agriculture in Europe. AGU, Abstract ID 1195341, San Francisco, Cal, USA.

Peyraud, J.L., Astigarraga, L., 1998. Review of the effect of nitrogen fertilization on the chemical composition, intake, digestion and nutritive value of fresh herbage: consequences on animal nutrition and $\mathrm{N}$ balance. Animal Feed Sc. Technol. 72, 235-259.

Ryan, M., Brophy, C., Connolly, J., McNamara, K., Carton, O.T., 2006. Monitoring of nitrogen leaching on a dairy farm during four drainage seasons, Irish J. Agric. Food Res. 45, 115-134.

Ryan, M., Sherwood, M., Fanning, A., 2001. Leaching of Nitrate-N $\left(\mathrm{NO}_{3}-\mathrm{N}\right)$ from cropped and fallow soil- a lysimeter study with ambient and imposed rainfall regimes. Irish Geography 34(1), 34-49.

Scholefield, D., Tyson, K.C., Garwood, E.A., Armstrong, A.C., Hawkins, J., Stone A.C., 1993. Nitrate leaching from grazed grassland lysimeters: Effects of fertiliser input, field drainage, age of sward and patterns of weather. J. Soil Sci. 44, 601-613.

Schulte, R.P.O., Diamond, J., Finkele, K., Holden, N.M., Brereton, A.J., 2005. Predicting the soil moisture conditions of Irish grasslands. Irish J. Agric. Food Res. 44, 95-110.

Schulte, R.P.O., Richards, K., Daly, K., Kurz, I., McDonald, E.J., Holden, N.M., 2006 Agriculture, meteorology and water quality in Ireland: a regional evaluation of pressures and pathways of nutrient loss to water. Biol. Environ. 106B, 53-69.

Toner, P., Bowman, J., Clabby, K., Lucey, J., McGarrigle, M., Concannon, C., Clenaghan, C., Cunningham, P., Delaney, J., O’Boyle, S., MacCárthaigh, M., Craig, M. Quinn, R., 2005. Water Quality in Ireland, 2001-2003. Environmental Protection Agency, Wexford, Ireland. 
Treacy, M., Humphreys, J., McNamara, K., Browne, R., Watson, C.J., 2008. Farm-gate nitrogen balances on intensive dairy farms in the south west of Ireland. Irish J. Agric. Food Res. 47, 105-117.

USEPA., 1983a. Nitrogen, nitrate-nitrite. Method 353.1 (colorimetric, automated, hydrazine reduction), In: Methods for chemical analysis of water and wastes, EPA-600/4-79-020. USEPA, Cincinnati, OH, pp. 353-1.1-353-1.5

Vickery, J.A., Bradbury, R.B., Henderson, I.G., Eaton, M.A., Grice, P.V., 2004. The role of agri-environment schemes and farm management practices in reversing the decline of farmland birds in England. Biol. Conserv. 119, 19-39.

Watson, C.J., Jordan, C., Lennox, S.D., Smith, R.V., Steen R.W.J., 2000. Inorganic nitrogen in drainage water from grazed grassland in Northern Ireland. J. Environ. Qual. 29, 225-232. 
Table 1 Summary of the treatments, Stocking rate (No. animal ha ${ }^{-1}$ ), system intensity, grassland management, grazing events (No. grazing time per year), nutrient source and rates applied $\left(\mathrm{kg} \mathrm{ha}^{-1}\right)$ to each treatment

\begin{tabular}{|c|c|c|c|c|c|c|c|c|c|c|}
\hline \multirow[t]{3}{*}{ Treatment } & \multirow[t]{3}{*}{ Intensity } & \multirow[t]{3}{*}{ Stocking rate } & \multirow[t]{3}{*}{ Grassland management } & \multirow[t]{3}{*}{ Grazing events } & \multicolumn{6}{|c|}{ Nutrient applications } \\
\hline & & & & & \multicolumn{3}{|c|}{ Fertiliser } & \multicolumn{3}{|c|}{ Manure } \\
\hline & & & & & Y1 & $\mathrm{Y} 2$ & Y3 & Y1 & Y2 & Y3 \\
\hline $\mathrm{T} 1$ & Intensive & 1.8 (bull); & grazed only & 7 & 269 & 188 & 212 & - & - & - \\
\hline $\mathrm{T} 2$ & Intensive & 1.4 (steer) & cut once for silage, grazed & 5 & 247 & 222 & 273 & 129 & 86 & 102 \\
\hline T3 & Intensive & & cut twice for silage, grazed & 4 & 220 & 245 & 245 & 129 & 86 & 102 \\
\hline $\mathrm{T} 4$ & REPS & 1.4 (bull); & grazed only & 7 & 57 & 57 & 57 & - & - & - \\
\hline T5 & REPS & $\int 1.1$ (steer) & cut once for silage, grazed & 5 & 114 & 114 & 114 & 98 & 70 & 102 \\
\hline
\end{tabular}


Table 2 Summary of the Least Significant Ratio comparison of individual treatments, identifying the year $(\mathrm{Y})$ when the mean annual soil solution $\mathrm{NO}_{3}{ }^{-}-\mathrm{N}$ concentrations were significantly different

\begin{tabular}{|c|c|c|c|c|c|}
\hline & Treatment & & & & \\
\hline Treatment & $\mathrm{T} 1$ & $\mathrm{~T} 2$ & $\mathrm{~T} 3$ & $\mathrm{~T} 4$ & T5 \\
\hline \multicolumn{6}{|l|}{$\mathrm{T} 1$} \\
\hline $\mathrm{T} 2$ & n.s & & & & \\
\hline $\mathrm{T} 3$ & n.s. & n.s. & & & \\
\hline $\mathrm{T} 4$ & Y2 \& 3 & Y3 & n.s. & & \\
\hline T5 & $Y 2 \& 3$ & $\mathrm{Y} 2 \& 3$ & $\mathrm{Y} 2 \& 3$ & n.s. & \\
\hline
\end{tabular}

n.s. no significant difference between mean treatment annual TON concentration. Annual LSRs were 4.0(Y1), 3.5 (Y2) and 3.7 (Y3).

$\mathrm{Y}$ signifies the year when the mean annual soil solution TON concentrations were significantly different $(\mathrm{P}<0.01)$ 
Table 3 Comparison of the number of sample dates $(\%)$, within a year, that the mean soil solution $\mathrm{NO}_{3}{ }^{-} \mathrm{N}$ concentrations above the specified LSR for the following comparisons. a. T4 and T1, b. T5 and T2 and c. T5 and T3 and the total number of sample dates each year

\begin{tabular}{lllll}
\hline Treatment comparison & Year 1 \%) & Year 2 $(\boldsymbol{\%})$ & Year 3 $(\boldsymbol{\%})$ & Total \\
\hline a. T4 < T1 & 55 & 10 & 60 & 23 \\
b. T5 < T2 & 11 & 38 & 95 & 27 \\
c. T5 < T3 & 16 & 100 & 100 & 37 \\
L.S.R. & 3.8 & 3.9 & 3.8 & \\
Probability & $<0.0001$ & $<0.05$ & $<0.01$ & \\
No. of sampling dates & 19 & 13 & 21 & 53 \\
\hline
\end{tabular}


Table 4 Mean annual $\mathrm{NO}_{3}{ }^{-} \mathrm{N}$ load leached $\left(\mathrm{kg} \mathrm{N} \mathrm{ha}^{-1} \mathrm{y}^{-1}\right)$ by treatment and year, the annual least significant ratio and the mean annual leaching load statistical summary comparing the means of $\mathrm{T} 4$ and $\mathrm{T} 1 ; \mathrm{T} 5$ and $\mathrm{T} 2$; and $\mathrm{T} 5$ and $\mathrm{T} 3$

\begin{tabular}{|c|c|c|c|c|c|c|}
\hline \multirow[b]{2}{*}{ Treatment } & & \multicolumn{3}{|c|}{ Year } & \multirow[b]{2}{*}{ Total } & \multirow[b]{2}{*}{ FracLeach $(\%)$} \\
\hline & & 1 & 2 & 3 & & \\
\hline $\mathrm{T} 1$ & & 24.2 & 13.0 & 17.6 & 54.8 & 8.2 \\
\hline $\mathrm{T} 2$ & & 8.7 & 13.8 & 41.4 & 63.9 & 6.0 \\
\hline $\mathrm{T} 3$ & & 6.7 & 44.9 & 19.1 & 70.7 & 6.9 \\
\hline $\mathrm{T} 4$ & & 6.6 & 8.4 & 4.6 & 19.7 & 11.5 \\
\hline T5 & & 9.6 & 3.5 & 1.9 & 15.0 & 2.5 \\
\hline \multirow[t]{2}{*}{$\mathrm{LSR} \uparrow$} & & 4.2 & 3.7 & 3.7 & 2.9 & 2.8 \\
\hline & & \multicolumn{3}{|c|}{ Year } & & \\
\hline $\begin{array}{l}\text { Statistical } \\
\text { comparisons }\end{array}$ & Treatment & 1 & 2 & 3 & Total & \\
\hline T4 v T1 & & n.s. & n.s. & $*$ & n.s. & \\
\hline $\mathrm{T} 5 \mathrm{v}$ T2 & & n.s. & $*$ & $* *$ & $*$ & \\
\hline T5 v T3 & & n.s. & $* *$ & $* *$ & $*$ & \\
\hline
\end{tabular}

$\dagger$ Least significant ratio; If the ratio of the larger mean to the smaller mean is greater than the LSR, then the two means differ significantly at the reported p-value; Treatment means are significantly different $\mathrm{p}<0.05(*)$ and $\mathrm{p}<0.01(* *)$ 
Table 5 Comparison of the nitrogen balance for the Intensive and REPS beef suckler systems over the 3 year study period

\begin{tabular}{lllllll}
\hline & Intensive & \multicolumn{3}{c}{ REPS } \\
Inputs & Y 1 & Y 2 & Y 3 & Y 1 & Y 2 & Y 3 \\
\hline Fertiliser (kg N/ha) & 248.3 & 214.0 & 235.7 & 90.1 & 90.1 & 90.1 \\
Concentrate feed (kg N/ha) & 30.5 & 30.5 & 31.6 & 24.5 & 24.9 & 26.0 \\
N deposition (kg N/ha)* & 9.0 & 9.0 & 9.0 & 9.0 & 9.0 & 9.0 \\
Total Inputs (kg N/ha) & 288 & 253 & 276 & 124 & 124 & 125
\end{tabular}

\section{Outputs}

Animal live weight gain ( $\mathrm{kg} \mathrm{N} / \mathrm{ha})$

$\begin{array}{llllll}11.4 & 12.0 & 13.0 & 9.2 & 9.6 & 10.6 \\ 28.8 & 25.3 & 27.6 & 12.4 & 12.4 & 12.5 \\ 3.1 & 2.7 & 2.9 & 1.1 & 1.1 & 1.1 \\ 13.2 & 23.9 & 26.0 & 8.1 & 6.0 & 3.3 \\ 58.5 & 63.7 & 66.7 & 31.0 & 28.7 & 27.3\end{array}$

Ammonia volatilisation ( $\mathrm{kg} \mathrm{N} / \mathrm{ha})^{* *}$

Denitrification (kg N/ha)***

$28.7 \quad 27.3$

Total Outputs

\begin{tabular}{lllllll} 
N not accounted for (input - output) & 229.3 & 189.8 & 209.6 & 92.6 & 95.3 & 97.7 \\
\hline *Calculated according to Ryan et al., $2006 ; * *$ Calculated as $10 \%$ of total input; $* * *$ Calculated according
\end{tabular}

\begin{tabular}{lllllll} 
N not accounted for (input - output) & 229.3 & 189.8 & 209.6 & 92.6 & 95.3 & 97.7 \\
\hline *Calculated according to Ryan et al., $2006 ; * *$ Calculated as $10 \%$ of total input; $* *$ Calculated according
\end{tabular} to the IPPC, $1.25 \%$ of total $\mathrm{N}$ fertiliser input 
Figure 1 Temporal variation of estimated daily drainage $\left(\mathrm{mm} \mathrm{d}^{-1}\right)$ from $01 / 09 / 02$ to 30/06/05.

Figure 2a-2c Temporal variation of mean weekly soil solution $\mathrm{NO}_{3}{ }^{-}-\mathrm{N}$ concentration $\left(\mathrm{mg} \mathrm{l}^{-1}\right)$ in year 1 (a) year 2 (b) and year 3 (c) for T1 Intensive grazing ( $\left.\boldsymbol{\square}\right)$, T2 Intensive one cut silage + grazing $(\boldsymbol{\Delta})$, T3 Intensive two cut silage + grazing $(\bullet)$, T4 REPS grazing $(\square)$ and T5 REPS 1 cut silage + grazing $(\triangle)$. 
Fig. 1

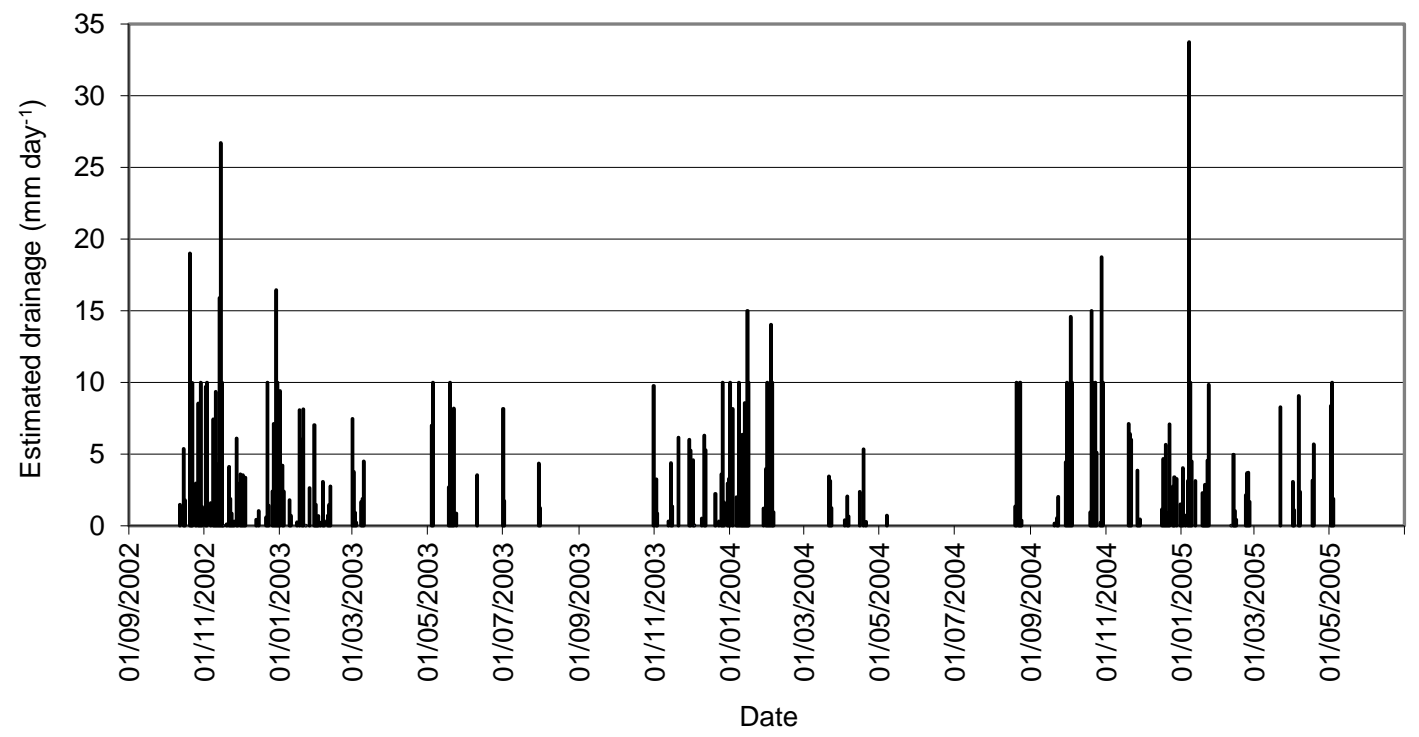


Figure 2a Year 1

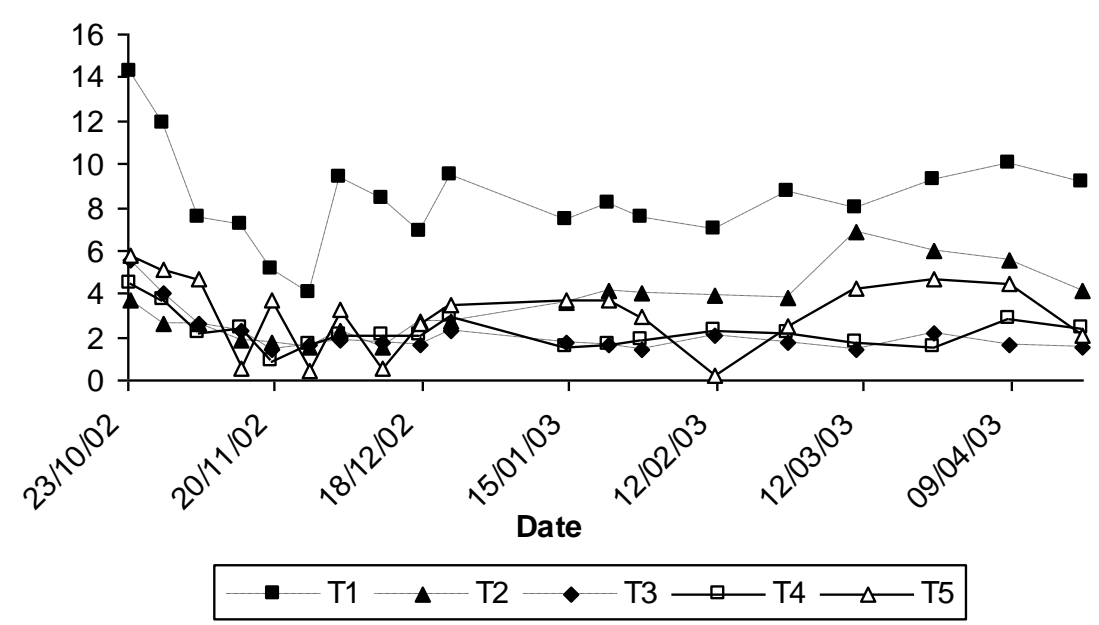

Figure $2 b$ Year 2

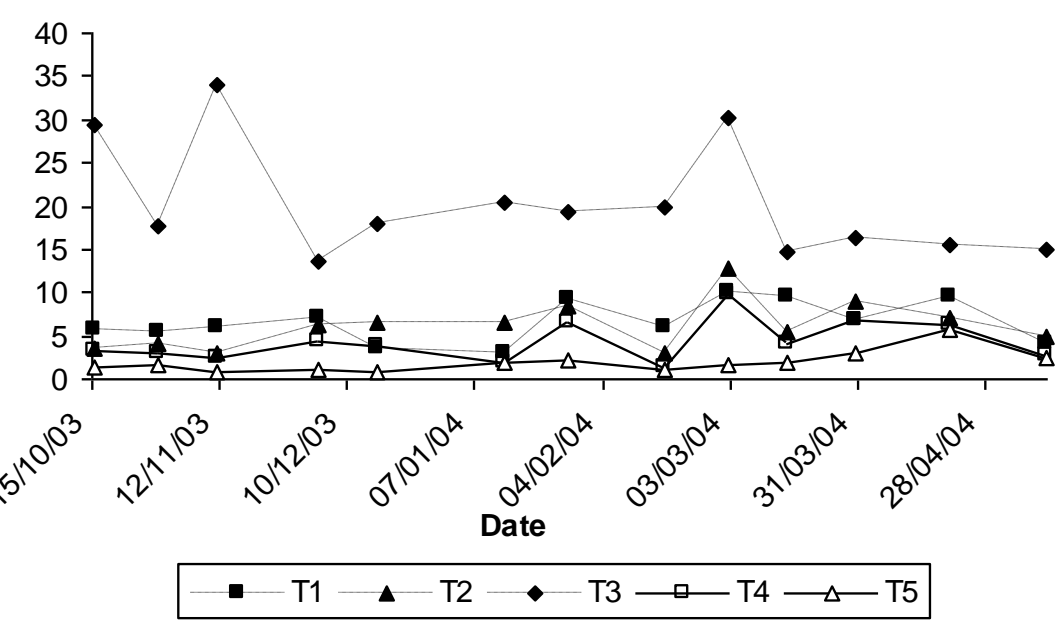

Figure 2c Year 3

LSR $=3.8$

LSR $=3.9$
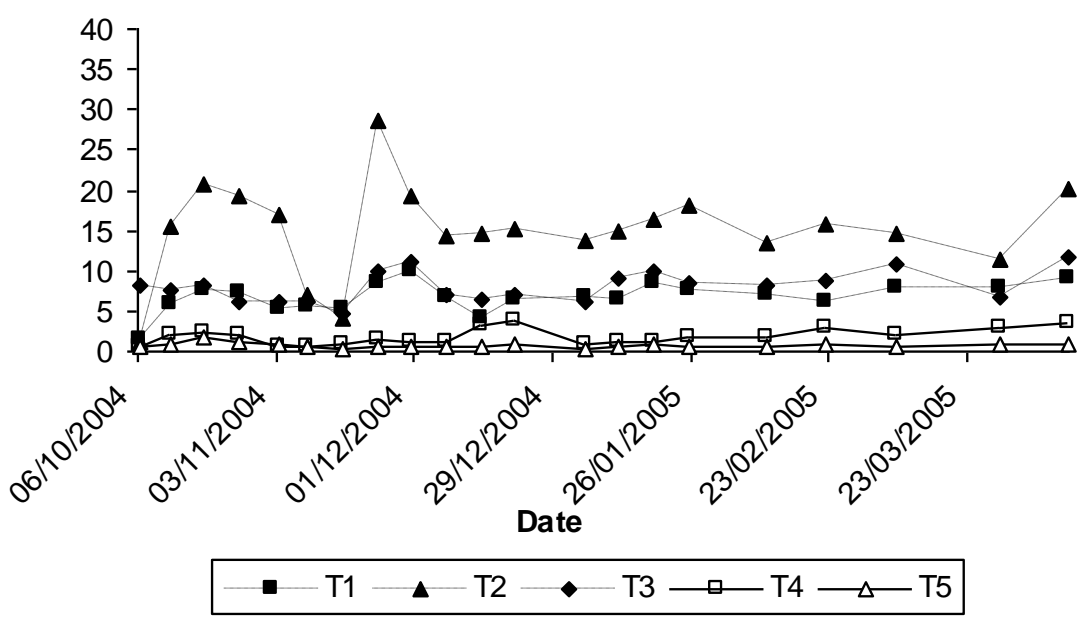